\title{
ORTHOPAEDIC PATIENTS' SATISFACTION WITH MEDICAL CLINIC AND EMERGENCY SERVICES PROVIDED IN SHAHID BEHESHTI HOSPITAL IN BABOL, NORTHERN IRAN
}

\author{
Mehdi Nikbin'1, Rahmatollah Jokar², Seyed Mokhtar Esmaeilnejad-Ganji ${ }^{3}$
}

1MD, Student Research Committee, School of Medicine, Babol University of Medical Sciences, Babol, Iran.

${ }^{2}$ Assistant Professor, Department of Orthopaedics, Babol University of Medical Sciences, Babol, Iran.

${ }^{3}$ Associate Professor, Clinical Research Development Centre, Shahid Beheshti Hospital, Babol University of Medical Sciences, Babol, Iran.

\begin{tabular}{l}
\hline ABSTRACT \\
BACKGROUND \\
Investigation of patients' satisfaction is one of the most common methods to evaluate the quality of hospital services. We aimed to \\
assess the orthopaedic patients' satisfaction with medical services, who were referred to the clinic and emergency of Shahid \\
Beheshti Hospital in Babol, Northern Iran.
\end{tabular}

\section{MATERIALS AND METHODS}

In this cross-sectional study, the orthopaedic patients who were referred between September 2017 and March 2018 were included. To evaluate the patients' satisfaction, we used the questionnaire standardised by the Minister of Health and Medical Education. Each item of the questionnaire scored on a 5-point Likert scale, ranging from 0 (Completely dissatisfied) to 4 (Completely satisfied). The emergency and clinic questionnaires had 22 and 17 questions, respectively. The total score of the two questionnaires was categorised as dissatisfied, moderately satisfied and completely satisfied.

\section{RESULTS}

Finally, 631 patients were evaluated in this study, of whom 342 were in the emergency group and 292 were in the clinic group. In the emergency group, the patients were mostly dissatisfied with the expenditures of the emergency unit. In the clinic group, the most dissatisfaction was related to lack of enough chairs in the waiting room, but the most satisfaction was with hospital medication preparation. Out of 342 patients in the emergency 51 (14.9\%) were completely satisfied, 265 (77.5\%) were moderately satisfied and $26(7.6 \%)$ were dissatisfied. Out of 292 clinic patients $11(3.8 \%)$ were completely satisfied, $264(90.4 \%)$ were moderately satisfied and 17 (5.8\%) were dissatisfied.

\section{CONCLUSION}

Satisfaction of the orthopaedic patients in emergency and clinic was mostly in the average level. Providing better services for the patients and comforting them affect their improvement positively.

\section{KEY WORDS}

Emergency, Clinic, Satisfaction, Orthopaedics.

HOW TO CITE THIS ARTICLE: Nikbin M, Jokar R, Ganji SME. Orthopaedic patients' satisfaction with medical clinic and emergency services provided in Shahid Beheshti Hospital in Babol, Northern Iran. J. Evolution Med. Dent. Sci. 2018;7(46):4977-4980, DOI: $10.14260 /$ jemds/2018/1107

\section{BACKGROUND}

Patients' comfort during staying in hospital is important due to his/ her pains. Making a comfort environment in hospital is in favour of patients and health workers both. The people who are responsible for patients' health will provide better conditions for faster improvement of patients in a quiet hospital environment with less tiredness and physical and mental stress.(1,2) Today, in the healthcare systems, it is necessary to respect the patients' needs and desires. The concentration of nursing care should be on factors affecting the patients' satisfaction. According to this, the nurses can increase their care quality. $(3,4)$ Qualitative development of healthcare professionals believe that it is necessary to determine, define and respond to the patients' needs. (5)

'Financial or Other Competing Interest': None.

Submission 03-10-2018, Peer Review 27-10-2018,

Acceptance 02-11-2018, Published 12-11-2018.

Corresponding Author:

Dr. Seyed Mokhtar Esmaeilnejad-Ganji,

Department of Orthopaedics,

Babol University of Medical Sciences,

Ganj Afrooz Street, Babol, Mazandaran, Iran.

E-mail: smsnganji@gmail.com

DOI: $10.14260 /$ jemds $/ 2018 / 1107$
Although, a lot of attempts are made to connect patients expectation and their satisfaction, lack of a mechanism for patients' satisfaction is still sensed.

Patients' satisfaction from health system is defined as meeting their different needs and achieving the predetermined objectives. It means that a patient who is more satisfied with medical staff function, he/ she will pay more attention to the therapeutic instructions and advices and will have a better function in selection of treatment method.(6) Components of a patient's satisfaction with healthcare include providing rest and comfort for them, addressing their nutritional needs, personal hygiene, supportive care, response to treatment, staff-patient relationship, physical environment, hospital fee and nurse availability.(7)

Considering the sensitivity of emergency in the health system of each region, decrease in the time and increase in the quality of delivery service to the patients are important. Also, the quick and appropriate management of the patients is another important issue, because it is not only one of the Ministry of Health aims, but also can increase the patients' satisfaction. ${ }^{(8)}$ In addition, given the high rate of referral to the emergency unit, the time is very important and providing the health services in this unit reflects the overall hospital 
health services status. Considering that quality of service provision in the emergency units is important in the evaluation of hospitals and the assessment of the rest of hospital wards is related to the necessary required limit and given that one of the important indices of quality of service provision in the emergency units is satisfaction level of referrals with the provided services.(9) Therefore, assessment of patients' satisfaction with the hospital services is important.

Hospitals usually face high rates of orthopaedic referrals (Emergency or Elective), which can affect how to manage the patients and provide services. Hence, the necessity of evaluation of orthopaedic patients' satisfaction is sensed. Considering that not any studies exist assessing the orthopaedic patients' satisfaction in Babol, we aimed to evaluate this issue.

\section{MATERIALS AND METHODS}

\section{Locations and Participants}

In this cross-sectional study, traumatic and non-traumatic patients were included, who were referred to Emergency Department and Orthopaedic Clinic of Shahid Beheshti hospital affiliated to Babol University of Medical Sciences between September 2017 and March 2018. Shahid Beheshti teaching hospital is a centre of trauma in Mazandaran province. The exclusion criteria were as follows: Lack orientation of the patient to time, place and person, lack of contribution in replying to the questionnaires, psychiatric diseases or psychiatric medications.

\section{Data Collection}

The demographic information (Age, gender, marital status, residence) were collected by a checklist. To evaluate the patients' satisfaction, we used the questionnaire standardised by the Minister of Health and Medical Education. This questionnaire was designed for the emergency unit and clinic separately. Each item scored on a 5-point Likert scale, ranging from 0 (Completely dissatisfied) to 4 (Completely satisfied). The emergency questionnaire had 22 questions and total score was categorised as dissatisfied ( 0 - 30 score), moderately satisfied (31 - 60 score) and completely satisfied (61 - 88 score). The clinic questionnaire had 17 questions and total score was classified as dissatisfied ( 0 - 22), moderately satisfied (23 - 44) and completely satisfied (45 - 68). About the literate patients the questionnaire was filled by them and regarding the illiterate patients the questionnaire was replied by interviewing. When the patient had not had a good general condition, the questions were asked from the companions. An average of 15 minutes (at least 10 minutes) was dedicated to each interview for every person.

\section{Statistical Analysis}

The collected data were analysed by SPSS software using descriptive analysis.

\section{Ethical Issues}

The aims of the study were explained to the patients and if agreed, those eligible were included in the research. The informed consent was obtained from all participants. The patients' information was kept confidential. This study was approved by the Ethics Committee of Babol University of Medical Sciences (code: MUBABOL.HRI.REC.1396.21).

\section{RESULTS}

In total 843 patients were primarily included in the study, of whom 212 were excluded due to meeting the exclusion criteria. Out of remaining 631 patients, 342 were related to the emergency group and 292 were related to the clinic group. The demographic information is summarised in Table 1.

Table 2 shows the rate of satisfaction of the emergency patients with the healthcare services. The most dissatisfaction was with oxygen therapy and the least was with the physician behaviour toward the patient. The most satisfaction pertained to the expenditures of the emergency unit.

Table 3 indicates the rate of satisfaction of the patients with the orthopaedic clinic. The most dissatisfaction was related to lack of enough chairs in the waiting room. The most satisfaction was related to hospital medication preparation and the least was related to waiting time in the clinic.

Out of 342 patients in the emergency, 51 (14.9\%) were completely satisfied, $265(77.5 \%)$ were moderately satisfied and $26(7.6 \%)$ were dissatisfied. Out of 292 clinic patients 11 (3.8\%) were completely satisfied, 264 (90.4\%) were moderately satisfied and 17 (5.8\%) were dissatisfied.

\begin{tabular}{|c|c|c|c|c|}
\hline \multirow[t]{2}{*}{ Variables } & \multicolumn{2}{|c|}{ Emergency $(n=342)$} & \multicolumn{2}{|c|}{ Clinic (n=292) } \\
\hline & Frequency & Percent & Frequency & Percent \\
\hline \multicolumn{5}{|c|}{ Age (Years old) } \\
\hline$<18$ & 69 & 20.2 & 56 & 19.1 \\
\hline $18-35$ & 216 & 63.2 & 164 & 56.2 \\
\hline$>35$ & 57 & 16.7 & 72 & 24.7 \\
\hline \multicolumn{5}{|l|}{ Gender } \\
\hline Female & 142 & 41.5 & 139 & 47.6 \\
\hline Male & 200 & 58.5 & 153 & 52.4 \\
\hline \multicolumn{5}{|l|}{ Marital Status } \\
\hline Married & 224 & 65.5 & 194 & 66.4 \\
\hline Unmarried & 118 & 34.5 & 98 & 33.6 \\
\hline \multicolumn{5}{|l|}{ Residence } \\
\hline Urban & 144 & 42.1 & 111 & 38 \\
\hline Rural & 198 & 57.9 & 181 & 62 \\
\hline \multicolumn{5}{|c|}{ Table 1. Patients' Characteristics } \\
\hline
\end{tabular}




\begin{tabular}{|c|c|c|c|c|c|c|c|c|c|c|}
\hline \multirow[t]{2}{*}{ Items } & \multicolumn{2}{|c|}{$\begin{array}{l}\text { Completely } \\
\text { Dissatisfied }\end{array}$} & \multicolumn{2}{|c|}{ Dissatisfied } & \multicolumn{2}{|c|}{$\begin{array}{c}\text { Partly } \\
\text { Satisfied }\end{array}$} & \multicolumn{2}{|c|}{ Satisfied } & \multicolumn{2}{|c|}{$\begin{array}{l}\text { Completely } \\
\text { Satisfied }\end{array}$} \\
\hline & $\mathbf{N}$ & $\%$ & $\mathbf{N}$ & $\%$ & $\mathbf{N}$ & $\%$ & $\mathbf{N}$ & $\%$ & $\mathbf{N}$ & $\%$ \\
\hline Were you received in the emergency easily? & 6 & 1.8 & 63 & 18.4 & 79 & 23.1 & 113 & 33 & 81 & 23 \\
\hline Were you evaluated by a nurse once entered? & 54 & 15.8 & 63 & 18.4 & 95 & 27.8 & 113 & 33 & 17 & 5 \\
\hline Were you examined by a physician once entered? & 18 & 5.3 & 80 & 23.4 & 83 & 24.3 & 106 & 31 & 55 & 16 \\
\hline Were the laboratory tests done immediately? & 39 & 11.4 & 120 & 35.1 & 136 & 39.8 & 40 & 11.7 & 7 & 2 \\
\hline $\begin{array}{l}\text { Were the imaging and other diagnostic methods } \\
\text { performed immediately? }\end{array}$ & 15 & 4.4 & 82 & 24 & 124 & 58 & 106 & 31 & 15 & 4.4 \\
\hline $\begin{array}{c}\text { Were your vital signs (blood pressure, pulse rate, } \\
\text { temperature and respiratory rate) controlled } \\
\text { immediately? }\end{array}$ & 12 & 3.5 & 94 & 27.5 & 124 & 36.3 & 93 & 28.1 & 16 & 4.7 \\
\hline Did you receive oxygen therapy immediately? & 75 & 21.9 & 182 & 53.2 & 73 & 21.3 & 7 & 2 & 5 & 1.5 \\
\hline Were your wounds dressed soon? & 4 & 1.2 & 41 & 12 & 169 & 49.4 & 115 & 33.6 & 13 & 3.8 \\
\hline Was your serum administered soon? & 12 & 3.5 & 99 & 28.9 & 120 & 35.1 & 99 & 28.9 & 12 & 3.5 \\
\hline $\begin{array}{l}\text { Were you satisfied with the nurses' behaviour in the } \\
\text { emergency unit? }\end{array}$ & 11 & 3.2 & 114 & 33.3 & 101 & 29.5 & 92 & 26.9 & 24 & 7 \\
\hline $\begin{array}{l}\text { Were you satisfied with the physician's behaviour in } \\
\text { the emergency unit? }\end{array}$ & 5 & 1.5 & 30 & 8.8 & 141 & 41.2 & 100 & 29.2 & 66 & 19.3 \\
\hline $\begin{array}{c}\text { Did other personnel (reception, workers, guard) of the } \\
\text { emergency behave well toward you? }\end{array}$ & 10 & 2.9 & 126 & 36.8 & 115 & 33.6 & 76 & 22.2 & 15 & 4.4 \\
\hline $\begin{array}{c}\text { Was the temperature of the emergency appropriate for } \\
\text { you (not very warm and not very cold? }\end{array}$ & 2 & 0.6 & 52 & 15.2 & 82 & 24 & 155 & 45 & 51 & 14.9 \\
\hline $\begin{array}{l}\text { Were the sheets, blankets and pillows accessible for } \\
\text { you? }\end{array}$ & 3 & 0.9 & 92 & 26.9 & 187 & 54.7 & 54 & 15.8 & 6 & 1.8 \\
\hline Was the toilet accessible for you? & 37 & 10.8 & 54 & 15.8 & 118 & 33.6 & 115 & 33.6 & 18 & 5.3 \\
\hline Was the wheelchair accessible for you? & 87 & 25.4 & 144 & 42.1 & 93 & 27.2 & 18 & 5.3 & 0 & 0 \\
\hline Was the stretcher accessible for you? & 75 & 21.9 & 87 & 25.4 & 112 & 32.7 & 52 & 15.2 & 16 & 4.7 \\
\hline Were your drugs given on time? & 0 & 0 & 75 & 21.9 & 105 & 30.7 & 129 & 37.7 & 33 & 9.6 \\
\hline Were you satisfied with the food quality? & 17 & 5 & 69 & 20.2 & 174 & 50.9 & 81 & 23.7 & 1 & 3 \\
\hline Was the environment of the emergency clean? & 31 & 9.1 & 154 & 45 & 125 & 36.5 & 30 & 8.8 & 2 & 0.6 \\
\hline Did you get expensive emergency care? & 23 & 6.7 & 35 & 10.2 & 66 & 19.3 & 136 & 39.8 & 82 & 24 \\
\hline Did nursing staff teach you the self-care training? & 0 & 0 & 85 & 24.9 & 126 & 36.8 & 106 & 31 & 25 & 7.3 \\
\hline
\end{tabular}

\begin{tabular}{|c|c|c|c|c|c|c|c|c|c|c|}
\hline \multirow[t]{2}{*}{ Items } & \multicolumn{2}{|c|}{$\begin{array}{l}\text { Completely } \\
\text { Dissatisfied }\end{array}$} & \multicolumn{2}{|c|}{ Dissatisfied } & \multicolumn{2}{|c|}{$\begin{array}{c}\text { Partly } \\
\text { Satisfied }\end{array}$} & \multicolumn{2}{|c|}{ Satisfied } & \multicolumn{2}{|c|}{$\begin{array}{l}\text { Completely } \\
\text { Satisfied }\end{array}$} \\
\hline & $\mathbf{N}$ & $\%$ & $\mathbf{N}$ & $\%$ & $\mathbf{N}$ & $\%$ & $\mathbf{N}$ & $\%$ & $\mathbf{N}$ & $\%$ \\
\hline $\begin{array}{l}\text { Could you easily make an appointment to visit your } \\
\text { physician? }\end{array}$ & 24 & 8.2 & 84 & 28.8 & 113 & 38.7 & 58 & 19.9 & 13 & 4.9 \\
\hline $\begin{array}{l}\text { Were you waiting for a long time to visit your } \\
\text { physician? }\end{array}$ & 37 & 12.7 & 140 & 47.9 & 85 & 29.1 & 18 & 6.2 & 12 & 4.1 \\
\hline Were your laboratory tests done easily? & 1 & 3 & 46 & 15.8 & 120 & 41.1 & 102 & 34.9 & 23 & 7.9 \\
\hline Were your laboratory tests expensive? & 0 & 0 & 33 & 11.3 & 88 & 30.1 & 124 & 42.5 & 47 & 16.1 \\
\hline Were the imaging procedures conducted easily? & 38 & 13 & 60 & 20.5 & 121 & 41.4 & 71 & 24.3 & 2 & 7 \\
\hline Was imaging expensive? & 0 & 0 & 81 & 27.7 & 123 & 42.1 & 75 & 25.7 & 13 & 4.5 \\
\hline Was your diagnosis identified? & 2 & 7 & 30 & 10.3 & 79 & 27.1 & 123 & 42.1 & 58 & 19.9 \\
\hline $\begin{array}{l}\text { Were you satisfied with the workers' behaviour in the } \\
\text { clinic? }\end{array}$ & 12 & 4.1 & 61 & 16.8 & 114 & 42.5 & 81 & 32.9 & 24 & 3.8 \\
\hline $\begin{array}{l}\text { Were you satisfied with your physician's behaviour in } \\
\text { the clinic? }\end{array}$ & 12 & 4.1 & 49 & 16.8 & 124 & 42.5 & 96 & 32.9 & 11 & 3.8 \\
\hline $\begin{array}{l}\text { Could you provide the drugs from the hospital } \\
\text { pharmacy? }\end{array}$ & 5 & 1.7 & 13 & 4.5 & 68 & 23.3 & 160 & 54.8 & 46 & 15.8 \\
\hline Were your drugs expensive? & 0 & 0 & 32 & 11 & 62 & 21.2 & 148 & 50.7 & 50 & 17.1 \\
\hline Was the clinic environment clean? & 46 & 15.8 & 108 & 37 & 104 & 35.6 & 34 & 11.6 & 0 & 0 \\
\hline Was the toilet accessible? & 10 & 3.4 & 39 & 13.4 & 135 & 46.2 & 80 & 27.4 & 28 & 9.6 \\
\hline Was the toilet clean? & 36 & 12.3 & 122 & 41.8 & 89 & 30.5 & 44 & 15.1 & 1 & 3 \\
\hline $\begin{array}{l}\text { Was the temperature of the clinic appropriate for you } \\
\text { (not very warm and not very cold? }\end{array}$ & 21 & 7.2 & 68 & 23.3 & 141 & 48.3 & 61 & 20.9 & 1 & 3 \\
\hline Were there enough chairs in the waiting room? & 78 & 26.7 & 135 & 46.2 & 65 & 22.3 & 131 & 4.5 & 1 & 3 \\
\hline Were there magazine, newspaper or television? & 64 & 21.9 & 125 & 42.8 & 70 & 24 & 31 & 10.6 & 2 & 7 \\
\hline luat & & 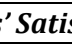 & 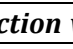 & & 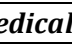 & - & & inic & & \\
\hline
\end{tabular}




\section{DISCUSSION}

In this study, we investigated the orthopaedic patients' satisfaction in clinic and emergency unit of Shahid Beheshti Hospital in Babol. Our findings showed a relative satisfaction with medical services in most of the patients. In the study by Ebrahimnia et al(10) in 2007, the most number of responses of "dissatisfied" and "completely dissatisfied" was related to hospital facilities and the least one was related to medical services. In the study by Zahmatkesh et al(9) in 2006 in Golestan province, in the emergency unit, the most satisfaction was with the attention and reception by the physician ( $86 \%)$ followed by attention and reception by the nurses (85\%), response to questions by nursing staff $(84.1 \%)$, ward environment temperature (83.9\%) and cleanliness of surfaces and floor (81.9\%). The least satisfaction pertained to behaviours of guards toward the patients and companions (33.8\%), followed by cleanliness of toilets (45.7\%). In the study by Nemati et al(7) in 2011 in Tehran, the most satisfaction was with the awareness about patients' questions and the least was related to accessibility to medical staff. Ansari et al(8) stated that the overall satisfaction of the patients was $67.3 \%$ with the clinic, $80.7 \%$ with the emergency, $72.2 \%$ with the hospital services and $86.5 \%$ with the emergency reception. A recent systematic review and meta-analysis by Ravaghi et al(11) reported that the mean satisfaction with emergency services was $70 \%$ in Iran showing higher satisfaction rate compared with the neighbouring countries. However, the authors proposed to increase the patients' satisfaction through appropriate training, information and increased human resources.

Satisfaction with imaging was more than satisfaction with laboratory tests in our study. This can be explained by emergency bustle and consequently delay in blood sampling by nurses. Also, laboratory bustle and lack of direct referral to the laboratory lead to delay in performing tests, because the patient should be referred to the imaging centre for imaging and consequently imaging procedure is done faster.

Another result of our study was that satisfaction with physician was more than the nurse, which can due to the patients' expectation. In fact, the patients expect more from a nurse, because they spend more time with him/ her than with a doctor. In addition, the nurses are responsible for handling the patients more than the physicians, leading to decrease in functional quality due to high rate of referrals.

High rate of dissatisfaction with oxygen therapy is related to lack of need to oxygen therapy in the orthopaedic patients and only few toxic patients with fractures admitted to cardiopulmonary resuscitation section needing oxygen therapy.

Our patients were satisfied with quick wound dressing, because the patients with laceration are transferred to the outpatient operating room and other therapeutic services are performed immediately. Satisfaction with food was high in the emergency unit, which can be related to socioeconomic level of the patients and their expectation from food.

Satisfaction with emergency and clinic expenditures and imaging and laboratory costs can be explained by the healthcare reform implemented recently. Dissatisfaction with making an appointment in the clinic and lack of enough chairs in the waiting room and wasting time to visit the physician in the clinic can be due to high rate of referrals. One of the limitations of our study was lack of collaboration in completing the questionnaires by the patients. Also, lack of favourable mental conditions of the patients during completing the questionnaires was another limitation.

\section{CONCLUSION}

The results showed that the patients in the clinic and emergency mostly had moderate satisfaction with the healthcare services. Providing better services for the patients and comforting them affect their improvement positively. It should also be stated that improving the service level is a step for improvement of hospital level.

\section{ACKNOWLEDGEMENT}

The authors would like to thank the Vice Chancellor for Research of Babol University of Medical Sciences for supporting our study.

\section{REFERENCES}

[1] Ahmadi B, Ziwdar M, Rafiei S. Patients' satisfaction in first rank Hospitals of Tehran University of Medical Sciences: a cross-sectional study in 2009. Journal of Payavard Salamat 2010;4(2):44-53.

[2] Makarem J, Larijani B, Joodaki K, et al. Patients' satisfaction with inpatient services provided in hospitals affiliated to Tehran University of Medical Sciences, Iran, during 2011-2013. J Med Ethics Hist Med 2016;9:6. eCollection 2016.

[3] Herrera CA, Stoerker J, Carlquist J, et al. Cell-free DNA, inflammation and the initiation of spontaneous term labor. Am J Obstet Gynecol 2017;217(5):583.e1-.e8.

[4] Kaushal P, Girdhar S, Chaudhary A, et al. Assessment of client's satisfaction regarding service utilization in an urban health centre in northern India. J Evolution Med Dent Sci 2015;4(58):10083-91.

[5] Bhattacharjya H, Das S. A study on satisfaction of patients attending OPD of Agartala government medical college. J Evolution Med Dent Sci 2014;3(17):4702-9.

[6] Toosi DT, Khalvat A, Najafizadeh S, et al. Medical student training and patient satisfaction in the internal medicine clinics of Imam Khomeini Hospital. JMED 2016;10(4):309-17.

[7] Nemati F, Mohammadnejad E, Tabatabaei A, et al. Satisfaction rate of hospitalized patients in teaching hospitals with presented services. Medical Ethics Journal 2014;8(28):29-50.

[8] Ansari H, Ebadi F, Mollasadeghi Gha. Evaluation of Patients Satisfaction in Hospitals under Iran University of Medical Sciences. J Birjand Univ Med Sci 2004;11(3):38-46.

[9] Zahmatkesh H, Hajimoradloo N, Malekmahmoodi Sh K. The assessment of patients satisfaction of hospital emergency departments - Golestan, Iran. J Gorgan Univ Med Sci 2010;12(3):91-6.

[10] Ebrahimnia M, Ameriun A, Farahani AM, et al. Satisfaction rate of hospitalized patients in military hospitals from presented services. J Mil Med 2010;12(2):101-5.

[11] Ravaghi H, Salemi M, Behzadifar M, et al. Patients' satisfaction with medical emergency services in Iran from 2000 to 2017: a systematic review and metaanalysis. Iran Red Crescent Med J 2018 (In Press):e58128. 